\title{
International supply chains: compliance and engagement with the Modern Slavery Act
}

\author{
HINRICH VOSS, MATTHEW DAVIS, \\ MARK SUMNER, LOUISE WAITE, ILSE A. RAS, \\ DIVYA SINGHAL and DEEPTI JOG
}

Abstract: The UK Modern Slavery Act aims to reduce and eradicate various forms of exploitation and is in this respect in line with the Sustainability Development Goal (SDG) 8.7. Section 54 of the act focusses on modern slavery in the international supply chain of organisations and obligates organisations to report on the actions they have taken to identify and address exploitation vulnerabilities. In order to understand how effective the current provisions in the act are, we analyse how businesses in the fashion and textile industry engage with the reporting requirements of Section 54 . While we find increasing compliance with the act, a significant share of fashion and textile businesses have not reported on their actions or have only filed a statement once.

Keywords: Fashion, modern slavery, Section 54, SDG 8.7, supply chains.

\section{INTRODUCTION}

The UN Sustainable Development Goals (SDGs) were established in 2015 with the objective of addressing key development challenges by 2030 that have not been adequately addressed through the UN's Millennium Development Goals (MDGs) (Sachs 2012, UN 2015). The seventeen SDGs expand significantly upon the eight MDGs and range from eliminating poverty and hunger, to providing affordable and sustainable infrastructures, and greater equity in the workplace (UN 2000a, 2015). They are broadly enough defined to encompass global operations of businesses, including their own operations and those of their supply chains (Kolk et al. 2017).

The potential reach of the SDGs across the global business operations of one company and its supply network is well illustrated by Goal 8. This Goal aims to achieve 'decent work for all', including the call for action in SDG 8.7 to take 'immediate and effective measures to eradicate forced labor, end modern slavery and human trafficking and secure the prohibition and elimination of the worst forms of child 
labour' (UN 2015). The explicit mentioning of modern slavery is new to the SDGs and therefore requires some clarification.

No commonly agreed upon definition of modern slavery exists and the term is not defined in any international instrument. The term modern slavery, however, increasingly circulates in policy, legislative, and civil society arenas and is used as an umbrella term to capture different forms of exploitation. These forms of exploitation include, but are not limited to, various forms of labour exploitation, such as forced labour. But they can also include human trafficking, forced marriage, and the removal of organs. In line with this broad approach is the modern slavery definition proposed by Kara (2017: 8), who argues that it is a 'system of dishonoring and degrading people through violent coercion of their labor activity in conditions that dehumanize them' and that this occurs 'regardless of compensation, ... because of the absence of a reasonable alternative' (Kara 2012: 31). Despite the lack of a common definition and thus agreed approach on how to collect data on modern slavery, the Walk Free Foundation (2018) has tried to estimate the extent of modern slavery and stated that in 2017 approximately 40 million people were in modern slavery, of whom 25 million people were in forced labour.

Exploitative labour conditions are, according to the US Department of Labor (2016), particular prevalent in the fashion and textile supply chain. The department lists workers in the cotton and cottonseeds, silk cocoons, textiles and embellished textiles, footwear, and garments sectors as being particularly vulnerable. The risks of modern slavery and labour exploitation in the fashion and textile sectors arise from the fragmented nature of their supply chains. The global supply chain is organised across multiple tiers of contract manufacturers and has a wide geographic spread, both across and within nations (Tokatli 2008). Brand owners tend to work closely with their domestic and global suppliers, with whom they have a contractual relationship. These suppliers are typically their first-tier suppliers. Suppliers beyond the first tier are often not known to brands and exist outside their immediate scope of influence. The opaque structure of the supply chain enables suppliers to outsource production to other businesses without an awareness of the ultimate source of their product and without assuming responsibility for due diligence along the entirety of the supply network. These characteristics of the fashion supply chain make monitoring for human rights abuses challenging (Gold et al. 2015, White et al. 2017) and contribute to the complex cultural, political, and business conditions that enable or facilitate the exploitation of individuals (Crane 2013).

Considering these complexities, achieving SDG 8.7 and reducing vulnerabilities require the concerted joint efforts of governments, businesses, and civil societies. One such effort is the UK Modern Slavery Act 2015. It provides a legislative framework for various forms of exploitation and explicitly obligates businesses to report annually on 
the efforts they have undertaken to identify, prevent, and address modern slavery in their supply chain (Section 54 of the act). These annual statements are the foundation for our research. Understanding how fashion and textile businesses engage and align with the reporting requirements in both letter and spirit provides some insights into the effectiveness of Section 54 of the act and how it could be developed further.

\section{CONTEXTUALISING THE MODERN SLAVERY ACT}

As previously explained, the term 'modern slavery' has been very broadly defined and this is also true within the act, covering forms of exploitation that are imminently relevant for global supply chains (e.g., forced labour, human trafficking, debt-bondage, bonded labour, and slavery (Kara 2017)) The bases for these terms are the ILO Forced Labour Convention (1930), the UN Supplementary Convention on the Abolition of Slavery, the Slave Trade, and Institutions and Practices Similar to Slavery (1956), and the 'Palermo Protocol' (UN 2000b). These conventions are global in force and jointly establish that any form of slavery be abolished and condemned. Yet, practices of slavelike exploitation persist, which has led to the specification of SDG 8.7 and the recent development of national legislation in various different countries (Dodds et al. 2017).

The California Transparency in Supply Chain Act (CTSCA) was the first domestic legislation requiring businesses to publish how they engage with modern slavery in their supply chain. The reporting requirements in the CTSCA are limited, however, and do not require businesses to regularly update the public on their efforts to address modern slavery. The transparency achieved is thus limited (Greer \& Purvis 2016, Koekkoek et al. 2017). The United Kingdom's Modern Slavery Act (MSA) addresses the transparency shortcoming by requiring businesses with an annual global turnover of $£ 36$ million or more and operations in the United Kingdom to release a statement on how they are trying to identify, prevent, and address modern slavery within their supply chain (Gadd \& Broad 2018).

Section 54 of the Modern Slavery Act requires companies to report how they are engaged in eradicating modern slavery from activities that pertain to their business operations. It further specifies that every company that 'carries on a business or part of a business in the UK' (Home Office 2017: 5) must produce such a statement and publish a copy on the homepage, or a similarly prominent position on its website, that has been signed off by a director or the closest equivalent. This statement has to cover the core business operations and its supply chain. The supply chain of a business is for this purpose defined as 'its everyday meaning' (Home Office 2017: 5). The business coverage and the inclusion of the global supply chain give the act an international reach to wherever businesses are sourcing from. 
Through this level of transparency and the possibility of public scrutiny of business conduct, the UK government has aimed to undermine the 'governance gap' of Western multinational enterprises and to 'create a race to the top' (Home Office 2017: 5) of appropriate business conduct and standards, as each business strives to become the most transparent, open, and forthright. This notion of transparency legislation surrounding modern slavery in supply chains rests on the argument that non-compliance may lead to increased scrutiny from the media and other civil society organisations. Public scrutiny and the finding of being non-compliant in letter or spirit and thus being labelled as a laggard in the move the address modern slavery can be severely damaging to the business's reputation and lead to revenue loss (Koekkoek et al. 2017). There is, however, much concern as to whether this happens in reality, and at a broader level whether corporate accountability legislative tools (such as Section 54) manage to meaningfully improve labour standards in business operations rather than acting to protect industry's commercial interests (LeBaron \& Ruhmkorf 2017).

\section{METHODS}

\section{Sample and data collection procedure}

Our research explores how fashion and textiles companies with an annual turnover over $£ 36$ million (US\$47.5 million) and operations in the United Kingdom respond to Section 54 of the act. We investigate their compliance with the legal reporting requirements by analysing their annual modern slavery statement and how they engage with the spirit of Section 54.

We assembled our sample of international fashion and textiles companies by, first, identifying companies on the Modern Slavery Registry (modernslaveryregistry.org) that were categorised as 'consumer durables \& apparel', 'retailing', or 'food \& staples retailing' businesses. The registry is an independent, non-governmental organisation (NGO) run open-access resource that is the de facto central depository to which businesses voluntarily submit their modern slavery statements (Business and Human Rights Resource Centre (BHRRC) 2017). Second, we used Fashion United's Top 100 fashion companies (fashionunited.com) and the FAME database compiled by Bureau van Dijk to identify businesses that operate in the United Kingdom and have a global turnover above the threshold of $£ 36$ million but which have not submitted their modern slavery statement to the registry. The led to an initial list of 365 companies. We removed companies that are in administration or liquidated, not involved in our focal industry (for example, textile production for the health or aerospace sectors), could not be clearly identified, or do not have a website. The act specified that, if a company has no 
website, it must provide a copy of the statement to anyone who requests it in writing. This left us with a sample of 332 businesses. We used the URLs provided within the registry and searched the company's website to locate and download the modern slavery statements for the years 2016 to 2018. When we searched the homepage of businesses, our starting point was the customer-facing homepage to determine whether or not the business is publishing a statement on its homepage rather than corporate or investor-facing websites. This choice has been made on the basis that Section 54 relies on the wider public to scrutinise company behaviour. The statements should therefore be available on websites that are frequently visited by the wider public, not by special interest groups.

Businesses operate different financial years, but the modern slavery statement is typically aligned with the financial year. The businesses in our sample have provided statements that cover a calendar year or a twelve-month period until April or June. In order to obtain comparable data, we collected statements that stretched over two years to the preceding year.

We analysed the extent to which companies comply with Section 54, by determining whether a company has a statement, where it publishes the statement on the website, and whether it is signed by a board member or not. This was followed by an analysis of how businesses report their activities around identifying and reducing modern slavery in their supply chains. Using the UK government guidance on how to interpret and work with the MSA, we report on the content of modern slavery statements. The content analysis provides further indications of the effectiveness of the Section 54 within the MSA.

\section{KEY FINDINGS}

We present first the findings from our compliance analysis of the modern slavery statements with the MSA, followed by a content analysis of the statements.

\section{Compliance with legal reporting requirements}

Section 54 of the Modern Slavery Act requires businesses to: (1) publish a modern slavery statement; (2) make it visible on the website; and (3) have a board member sign it. The business reporting on modern slavery has increased considerably over the last three years (see Table 1). While only 19 per cent of our sample had a statement in the first year of reporting, this share increased to nearly 40 per cent for 2017 and 2018. It should be noted that the number for 2018 is, however, an under-representation of the modern slavery reporting because companies often retrospectively report on their 
Table 1. Fashion and textile business compliance with Section 54 of the Modern Slavery Act $(N=332)$.

\begin{tabular}{lcrr}
\hline & $\mathbf{2 0 1 6}$ & \multicolumn{1}{c}{$\mathbf{2 0 1 7}$} & \multicolumn{1}{c}{$\mathbf{2 0 1 8}$} \\
\hline Business provides statement & $63(19 \%)$ & $117(35 \%)$ & $118(36 \%)$ \\
located on the homepage & $42(67 \%)$ & $80(68 \%)$ & $81(69 \%)$ \\
signed & $59(97 \%)$ & $100(94 \%)$ & $95(87 \%)$ \\
located on the homepage and signed & $39(64 \%)$ & $72(62 \%)$ & $70(60 \%)$ \\
\hline
\end{tabular}

Source: authors.

actions and achievements - consequently some companies may not have finalised their statement for 2018 at the time our analysis was completed. Plus there is the issue of possible time delays between their actions and reporting. Available modern slavery statements indicate that businesses often publish their statement more than half a year after the financial year has finished. The data reported here are therefore indicative of a further increase in modern slavery reporting.

In our analysis period of 2016-18, about two thirds of the fashion and textile businesses in our sample linked their statement on their homepage. Companies that do not provide a link have filed their statements under terminologies that are indicative of the content but do not mention modern slavery directly; such as an ethical statement or human rights report. This positioning of the modern slavery statement relates it to the broader corporate social responsibility of the company and suggests that the activities towards modern slavery are intertwined with other activities within a corporate social responsibility portfolio. Other firms have filed the modern slavery statement under terminologies that make it difficult to locate their statement (such as 'certificates', 'legal terms', 'legal \& cookies', or 'legal area, compliance, corporate policies and policy documents', 'statements and media statements', 'governance', 'about us', 'other company information', 'help'). The reasons for filing the modern slavery statements under labels that make them difficult to locate are not clear and not discernible from the available data. A possible explanation is that businesses are concerned about the reputational risk when they prominently refer to modern slavery on their homepage. A cursory reader may misinterpret and misconstrue any visible reference to modern slavery. The possible negative influence of making the modern slavery statement easily available is contrasted to many large, consumer-facing businesses in the public eye that transparently present their modern slavery statements. Businesses that have not published their statement on the homepage typically include suppliers and smaller businesses.

Our data suggest that the share of businesses fully complying with the act (producing, signing, locating statement on homepage) has remained stable within our sample over the years. While the release of modern slavery statements has increased, the share of firms that do not visibly publicise their statements has hardly changed. 
Despite the increasing compliance with the requirement to publish a statement in absolute terms, the analysis of the modern slavery statements has brought to light that businesses do not update their statements annually, update them with significant delay to their financial year, and do not clearly indicate the year of publication or time period covered. These constraints limit the transparency and undermine public assessment of corporate conduct.

\section{Content analysis of modern slavery statements}

Beyond the compliance measure specified in Section 54, the act outlines six further points that companies are advised ('may') to cover in their statements (Modern Slavery Act 2015):

(a) the organisation's structure, its business and its supply chains (business structure);

(b) its policies in relation to slavery and human trafficking (modern slavery policies);

(c) its due diligence processes in relation to slavery and human trafficking in its business and supply chains (due diligence process);

(d) the parts of its business and supply chains where there is a risk of slavery and human trafficking taking place, and the steps it has taken to assess and manage that risk (risk assessment);

(e) its effectiveness in ensuring that slavery and human trafficking is not taking place in its business or supply chains, measured against such performance indicators as it considers appropriate (key performance indicators);

(f) the training about slavery and human trafficking available to its staff (training).

Corporate approaches to these statements range from minimal disclosure, through to proactive discussion regarding procedures, and practices in place, together with acknowledging risks identified within the business operations.

\section{Motivation for publishing a modern slavery statement}

Our analysis shows that the majority of businesses commonly provide two reasons why they produce a modern slavery statement. The most often given reason is it being part of the company's values to trade ethically; the second most frequent reason is the fact that it is a legal duty. Companies that give further justification include Asda, ASOS, Kering, Pentland, H\&M, and Tesco. Swedish global mid-market brand H\&M is unusual in drawing attention to the relative responsibility that it carries to act on issues such as modern slavery, due to its size and influence in the industry. In contrast, German luxury brand Hugo Boss gives only one reason for creating a statement, which is that it is a legal duty. 
The language and explanation regarding motivation suggest that few companies appear to have considered who the audience of their statements may be, beyond the parties they collaborate with. It is noteworthy that only Camira, FatFace, John Lewis, Kering, Marks \& Spencer, Primark, Sainsburys, Ted Baker, and Tesco indicate the possible beneficiaries, which are, primarily, customers, in the sense that these companies 'know that [their] customers share [their] concern' (Marks \& Spencer 2017), and 'want [their] customers to be confident' (Camira 2015) that the products they buy are produced ethically.

\section{Business structure}

Brands often provide some information about their business and the structure of their supply chains, although the level of detail varies considerably. For example, American brand Urban Outfitters produces a very limited overview of its business, focussing primarily on its organisational structure in the sense of which parts of the company are covered by their modern slavery statement. Similarly, US luxury brand Michael Kors, German luxury brand Hugo Boss, and French luxury brand Louis Vuitton similarly give limited information about their suppliers. UK luxury brand Burberry acknowledges that it has different supply chains for resale products and services contracted to facilitate its business operations, but again the information given about each type of supply chain is minimal.

ASOS, on the other hand, produces a detailed example of a supply-chain map, and differentiates between supply chains for goods that are, and those that are not, for resale. The latter of these also includes also all contracted services. M\&S does not produce a detailed supply-chain map in its modern slavery statement, but instead redirects readers to an interactive website that shows the supply-chain map, and to which content appears to be added as M\&S further maps the supply chain for their wide range of products. New Look offers a graphic representation of its model supply chain. These examples stand out as instances of going beyond the brief overviews provided by the majority of the sample.

In contrast, Michael Kors limits itself to a brief paragraph on the structure of the supply chain, and Hugo Boss gives it a sentence. Louis Vuitton similarly gives limited information about its suppliers. Burberry acknowledges that it has different supply chains for resale products and services contracted to facilitate its business operations, but again the information given about each supply chain is minimal.

\section{Modern slavery policies}

Our analysis shows that all companies in our sample often refer to a code of conduct and/or an anti-slavery policy that their suppliers should adhere to. Companies such as ASOS, Debenhams, H\&M, John Lewis, Kustom Kit, M\&S, Mothercare, New Look, 
Next, Pentland, Primark, Sainsburys, Shop Direct, Ted Baker, and Tesco regulate eight or more aspects of work. Surprisingly, two smaller organisations, Dr Martens and Michael Kors, also provide higher levels of detail regarding their supplier codes of conduct. Sports Direct's description is extremely minimal. Other minimalists include B\&M, FatFace, Hugo Boss, Louis Vuitton, and Superdry, with Louis Vuitton noting that its code of conduct is 'available upon request' (Louis Vuitton 2017).

Analysis against our thematic framework, derived from a range of MSA statement advice documents and policies, demonstrates that companies based their code of conduct on at least one source of information beyond the statutory guidance. Primary sources of information include the ETI Base Code (2017), the UN Global Compact, and ILO guidance. A select few, including Burberry, Kering, Mizuno, Net a Porter, Primark, and Sainsbury, indicate consulting three or more sources.

\section{Due diligence processes}

Only H\&M and ASOS indicate specific incentives for suppliers to comply with their code of conduct, but even these make only cursory reference to rewarding 'good business partner performance' (H\&M 2016). Perhaps many of these companies consider their custom sufficient incentive for suppliers to consider complying, despite the reported difficulty of having sufficient leverage over suppliers to actually create change.

Few companies provide much detail regarding how they work with their suppliers. Whilst many note that they have worked with certain suppliers for a long time, and/or that they have a good-quality relationship with these suppliers, only Pentland focusses on when it, in general, pays its suppliers whilst M\&S and Tesco state that they specifically invite supplier feedback.

One topic highlighted in previous assessments of modern slavery statements is the lack of information on companies' risk assessment strategies (CORE 2017, ERGON Associates 2016, Sancroft \& Tussell 2018). This result is also replicated in our study of the fashion and textile sector. Whilst the majority of statements make reference to risk assessments, little in-depth information is given about the methods of risk assessment and the external sources and reports consulted. That said, some companies do go above and beyond in their description of the assessment process: H\&M, John Lewis, Marks \& Spencer, Pentland, Primark, Sainsburys, and Tesco are especially thorough compared to other companies.

The majority of companies in the data set are quite detailed in their description of the auditing process, noting, at the very least, who carries out the audits, which suppliers are audited, and the auditing approach. Further items that are covered by some businesses include the number of audits performed, and whether these audits were announced, semi-announced, or unannounced. A noteworthy exception here is 
Sports Direct, which does not refer at all to auditing suppliers to ensure no slavery is taking place.

\section{Remediation}

All companies make at least some reference to remediation, even if in a very generic sense. Especially detailed reports are made by John Lewis, Marks \& Spencer, Next, Primark, Sainsburys, and Tesco, whilst both H\&M and Hugo Boss could be considered mid-level. The main steps taken by companies in this data set include working with suppliers to remediate the risks and issues found during audits, with recourse to simply terminating contracts if the supplier is unable or unwilling to make the necessary changes. This also includes training suppliers. Information on the training methods and frequencies tends to be limited. The topics on which suppliers are trained include recognising modern slavery, implementing the supplier code of conduct, and, more specifically, training on the needs of migrant workers, on recruitment, on child labour, and on health and safety. Debenhams, John Lewis, M\&S, New Look, Primark, Sainsburys, and Tesco are particularly detailed in their description of supplier training. A small proportion of companies also indicate that they do work around raising awareness and 'embedding respect for human and labour rights', although few companies point out their methods for raising awareness.

The companies that provide the most detail about the steps they take to remediate modern slavery are also the companies that collaborate with a greater number of other companies, civil society organisations, governmental agencies, and other stakeholders to achieve leverage and create lasting change. Those citing high levels of external collaboration include Asda, ASOS, and H\&M. Those highly active companies also tend to be the ones explaining why they take their remediating steps, and why they collaborate (generally, to enhance their leverage and impact). It appears that there is at least some link between formulating the reasons for doing remediation work and being relatively detailed in describing this work.

\section{Key performance indicators}

Our analysis shows that there was little transparency regarding review processes amongst our sample. Furthermore, there was very limited identification of progress indicators, with a few exceptions, for companies to track the effectiveness of their remediation work.

M\&S, Mothercare, Primark, Ruia, Sainsburys, Shopdirect, and Tesco either actively sought out external advice on improving their remediation work, or were commended for the work that they were already doing. Other companies, when describing their process for achieving and measuring progress, simply refer to key performance indicators (KPIs) general review processes, and make high-level 
references to progressing over the coming year. Companies that provide actual data, include John Lewis, M\&S, Sainsburys, and Tesco. Although transparency regarding actual performance may be limited, many other brands do map the steps they have taken towards commitments and risks, thereby demonstrating progress.

\section{Training}

Most companies give some detail about staff training. Marks \& Spencer, Morrisons, Mothercare, New Look, Pentland, Primark, Ruia, Sainsburys, and Superdry offer relatively detailed reports, for example. Almost no companies, with the exception of Marks \& Spencer, New Look, and Morrisons, provide relevant detail about the methods and frequencies of staff training. The topics covered in training are 'identifying and responding to modern slavery', and the various policies and codes of conduct the company may have. ASOS, John Lewis, and M\&S specifically note that they train their buyers in responsible purchasing, and most other brands note that they specifically target the buying teams in their staff training.

\section{Governance and challenges}

ASOS, Burberry, John Lewis, N Brown, Primark, Superdry, and Tesco point out that they have employees working on sustainability and corporate responsibility issues in sourcing countries, or generally overseas. Others, such as M\&S, actually provide a schematic governance structure, but little narrative information.

Finally, there is limited acknowledgment of the challenges these companies face in tackling modern slavery issues. Those that do acknowledge limitations are Arcadia, ASOS, B\&M, H\&M, IC Group, Kering, M\&S, N Brown, Next, and Pentland; the most often mentioned challenge is that of balancing the need to trade ethically with other commercial pressures, with the challenge of resourcing the tracing of the supply chain (primarily in terms of time) the second most cited reason. The latter concern is brought up by $\mathrm{H} \& \mathrm{M}$ and $\mathrm{M} \& S$, which both have relatively extensive experience in mapping supply chains. There are other concerns around the fear of unintended consequences and the difficulty in identifying modern slavery and having real, lasting impact. In other words, those that indicate that they go to great lengths to identify slavery in their supply chains and remediate it, are those most willing to admit that their task is a very difficult one.

\section{DISCUSSION AND CONCLUSION}

The analyses of the first tranche of modern slavery statements (2016-18) within the fashion and textile sector indicate that companies have increased their modern slavery reporting and that the content of those statements varies significantly in topics 
addressed and depth provided. The MSA is a relatively recent act and the analysis suggests that it has limitations in its implementation and lacks meaningful enforcement. Over time, businesses and policy makers come to understand how best to interpret the objectives of the act and to operationalise these. To this end, the Home Office (2017) has updated the statutory guidance with stronger and clearer language. Businesses for their part are advancing their reporting, which is often becoming more detailed. But whilst large, consumer-facing businesses have relatively detailed reports, even these firms could be more detailed in how they engage with their global supply chain in an effective manner to support suppliers in complying with their often very detailed codes of practice. Our findings suggest that Section 54 of the MSA is currently not as effective as intended. Section 54 has required businesses to be more transparent with their approaches towards modern slavery within their global supply chains. But the lack of enforceable reporting standards on modern slavery engagement coupled with the absence of any meaningful penalties mean that the modern slavery statements vary significantly in quality and depth. Consequently, a large number of businesses have not yet engaged visibly with the act by releasing a statement. These initial observations (part of a larger research project) reinforce the recent calls by parliamentarians, civic society groups, and businesses themselves, for Section 54 to be strengthened to provide a level playing field for those businesses actively engaging in, and reporting on, the reduction of risk of labour exploitation in their supply chains. Such action requires much greater scrutiny, sanction, and enforcement against those companies neglecting their responsibilities in this space and reassurance to those firms which do report honestly (with the potential negative perceptions that identifying and sharing information about the exploitation found within one's own supply chain may bring).

\section{REFERENCES}

BHRRC (2017), 'Modern Slavery Registry', Business and Human Rights Resource Centre, available from https://www.modernslaveryregistry.org/ [accessed 1 November 2017].

California Transparency in Supply Chains Act (2010) SB657. http://www.state.gov/documents/organization/164934.pdf

Camira (2015), 'Modern Slavery Statement from Camira Fabrics'. https://www.camirafabrics.com/help/modern-slavery-statement [accessed 13 July 2018].

CORE (2017), 'Risk Averse? Company Reporting on Raw Material and Sector-specific Risks under the Transparency in Supply Chains Clause in the UK Modern Slavery Act 2015', CORE, London. https://corporate-responsibility.org/risk-averse-company-reporting-raw-material-sector-specific-riskstransparency-supply-chains-clause-uk-modern-slavery-act-2015/

Crane, A. (2013), 'Modern Slavery as a Management Practice: Exploring the Conditions and Capabilities for Human Exploitation', Academy of Management Review, 38(1): 49-69. https://doi.org/10.5465/amr.2011.0145 
Dodds, F., Donoghue, D. \& Roesch, J. L. (2017), Negotiating the Sustainable Development Goals: A Transformational Agenda for an Insecure World (London, Routledge). https://doi.org/10.4324/9781315527093

ERGON Associates (2016), 'Reporting on Modern Slavery: The Current State of Disclosure-May 2016', ERGON Associates, London.

https://ergonassociates.net/wp-content/uploads/2017/06/Reporting-on-Modern-Slavery2-May2016.pdf?x74739

ETI (2017), 'Base Code Guidance: Modern Slavery'.

https://www.ethicaltrade.org/sites/default/files/shared_resources/eti_base_code_guidance_modern_ slavery_web.pdf

Gadd, D. \& Broad, R. (2018), 'Troubling Recognitions in British Responses to Modern Slavery', British Journal of Criminology. https://doi.org/10.1093/bjc/azx082

Gold, S., Trautrims, A. \& Trodd, Z. (2015), 'Modern Slavery Challenges to Supply Chain Management', Supply Chain Management: An International Journal, 20(5): 485-94.

https://doi.org/10.1108/SCM-02-2015-0046

Greer, B. T. \& Purvis. J. G. (2016), 'Corporate Supply Chain Transparency: California's Seminal Attempt to Discourage Forced Labour', The International Journal of Human Rights, 20(1): 55-77. https://doi.org/10.1080/13642987.2015.1039318

H\&M (2016), 'The H\&M Group Modern Slavery Statement Financial Year 2015/2016'.

http://sustainability.hm.com/content/dam/hm/about/documents/en/CSR/Report\%202016/ HMgroup_Modern_Slavery_Statement_2015-2016.pdf [accessed 13 July 2018].

Home Office (2017), 'Transparency in Supply Chains etc. A Practical Guide'.

https://assets.publishing.service.gov.uk/government/uploads/system/uploads/attachment_data/ file/649906/Transparency_in_Supply_Chains_A_Practical_Guide_2017.pdf

ILO (1930) Forced Labour Convention (Geneva, International Labour Organization).

https://www.ilo.org/wcmsp5/groups/public/---asia/---ro-bangkok/documents/genericdocument/ wcms_346435.pdf

Kara, S. (2012), Bonded Labor: Tackling the System of Slavery in South Asia (New York, Columbia University Press). https://doi.org/10.7312/kara15846

Kara, S. (2017), Modern Slavery: A Global Perspective (New York, Columbia University Press).

Koekkoek, M., Marx, A. \& Wouters, J. (2017), 'Monitoring Forced Labour and Slavery in Global Supply Chains: The Case of the California Act on Transparency in Supply Chains', Global Policy, 8(4): 522-9. https://doi.org/10.1111/1758-5899.12512

Kolk, A., Kourula, A. \& Pisani, N. (2017), 'Multinational Enterprises and the Sustainable Development Goals: What Do We Know and How to Proceed?', Transnational Corporations, 24(3): 9-32. https://doi.org/10.18356/6f5fab5e-en

LeBaron, G. \& Ruhmkorf, A. (2017), 'The Domestic Politics of Corporate Accountability Legislation: Struggles Over the 2015 UK Modern Slavery Act', Socio-Economic Review. https://doi.org/10.1093/ser/mwx047.

Louis Vuitton (2017), 'UK Modern Slavery Act 2015 Statement'. https://uk.louisvuitton.com/eng-gb/modern-slavery-act-uk [accessed 13 July 2018].

Marks \& Spencer (2017), 'Modern Slavery Statement 2017'. https://corporate.marksandspencer.com/documents/plan-a-our-approach/mns-modern-slaverystatement-june2017.pdf [accessed 13 July 2018].

Modern Slavery Act 2015. (c.30) (London, The Stationery Office). http://www.legislation.gov.uk/ukpga/2015/30/contents/enacted

Modern Slavery Registry (no date). https://www.modernslaveryregistry.org/ [accessed 30 July 2018].

Sachs, J. D. (2012), 'From Millennium Development Goals to Sustainable Development Goals', The Lancet, 379(9832): 2206-11. https://doi.org/10.1016/S0140-6736(12)60685-0 
Sancroft \& Tussell (2018), 'The Sancroft-Tussell Report: Eliminating Modern Slavery in Public Procurement', Sancroft, London.

https://sancroft.com/2018/03/22/the-sancroft-tussell-report-eliminating-modern-slavery-in-publicprocurement/

Tokatli, N. (2008), 'Global Sourcing: Insights from the Global Clothing Industry-The Case of Zara, A Fast Fashion Retailer', Journal of Economic Geography, 8(1): 21-38. https://doi.org/10.1093/jeg/lbm035

UK Parliament (2018a), 'Modern Slavery (Transparency in Supply Chains) Bill', [HL] 2016-17. https://services.parliament.uk/Bills/2016-17/modernslaverytransparencyinsupplychains.html.

UK Parliament (2018b), 'Modern Slavery (Transparency in Supply Chains)', Bill [HL] 2017-19. https://services.parliament.uk/bills/2017-19/modernslaverytransparencyinsupplychains.html

UK Parliament (2018c), 'Transparency in UK Company Supply Chains (Eradication of Slavery)', Bill 2012-13.

https://services.parliament.uk/bills/2012-13/transparencyinukcompanysupplychainseradication ofslavery.html

UN (1956), Supplementary Convention on the Abolition of Slavery, the Slave Trade, and Institutions and Practices similar to Slavery, United Nations Treaty Series, vol. 266, No. 3822, p. 3.

https://www.ohchr.org/en/professionalinterest/pages/supplementaryconventionabolitionofslavery. aspx

UN (2000a), United National Millennium Declaration. A/RES/55/2, 18 September. https://undocs.org/A/RES/55/2

UN (2000b), Protocol to Prevent, Suppress and Punish Trafficking in Persons Especially Women and Children, United Nations Treaty Series, vol. 2237, No. 39574, p. 319.

https://www.unodc.org/documents/treaties/Special/2000_Protocol_to_Prevent_2C_Suppress_ and_Punish_Trafficking_in_Persons.pdf

UN (2015), Transforming our World: The 2030 Agenda for Sustainable Development. A/RES/70/1, 25 September. https://undocs.org/A/RES/70/1

UN (2017), UN Guiding Principles Reporting Framework with Implementation Guidance.

https://www.ungpreporting.org/wp-content/uploads/UNGPReportingFramework_withguidance 2017.pdf

US Department of Labour (2016), 'List of Goods Produced by Child Labor or Forced Labor'. https://www.dol.gov/ilab/reports/child-labor/list-of-goods/

Walk Free Foundation (2018), 'Global Slavery Index 2018'. https://www.globalslaveryindex.org/

White, C. L., Nielsen, A. E. \& Valentini, C. (2017), 'CSR Research in the Apparel Industry: A Quantitative and Qualitative Review of Existing Literature', Corporate Social Responsibility and Environmental Management, 24(5): 382-94. https://doi.org/10.1002/csr.1413

Notes on the authors:

Hinrich Voss is Professor of International Business at Leeds University Business School. He is researching the internationalisation of firms to and from emerging markets and the relationship between multinational enterprises and institutions.

h.voss@leeds.ac.uk

Matthew Davis is an Associate Professor in Organizational Psychology at Leeds University Business School and an Associate Fellow of the British Psychological Society. He is interested in how people interact with their environments and how 
businesses engage in CSR (corporate social responsibility), particularly to address sustainability and modern slavery.

m.davis@leeds.ac.uk

Mark Sumner is Lecturer in Sustainability, Retail and Fashion at the School of Design at the University of Leeds. His research focusses on sustainability within the textile, clothing, and fashion industry with a particular emphasis on how retailers and their supply networks interact in their pursuit of consumer demand. The importance of understanding the consumer within the sustainability dialogue is key aspect of this research.

M.P.Sumner@leeds.ac.uk

Louise Waite is Professor of Human Geography at the University of Leeds. Her research interests span migration and slavery; with a particular focus on discourses of 'modern slavery', unfree/forced labour, and exploitative work among asylum seekers and refugees. She has published on these themes in a range of peer-reviewed journals and in recent books: The Modern Slavery Agenda: Politics, Policy and Practice in The UK (with G. Craig, A. Balch \& H. Lewis, Policy Press, 2019), Vulnerability, Exploitation and Migrants: Insecure Work in a Globalised Economy (with H. Lewis, G. Craig \& K. Skrivankova, Palgrave Macmillan, 2015) and Precarious Lives: Forced Labour, Exploitation and Asylum (with H. Lewis, S. Hodkinson \& P. Dwyer, Policy Press, 2014). 1.waite@1eeds.ac.uk

Ilse A. Ras completed her PhD in English Language at the University of Leeds and an MSc in Criminology at the University of Leicester. She is a co-founder of the Poetics and Linguistics Association Special Interest Group on Crime Writing. Her work and teaching often crosses the boundaries between English language and criminology, using corpus-assisted critical discourse analysis and critical stylistics to examine how language links to crime.

i.a.ras@live.nl

Divya Singhal is an Associate Professor in the General Management area at Goa Institute of Management (GIM), India. She is leading the Centre for Social Sensitivity and Action at GIM. Her research interest lies in the area of development, education, gender, social responsibility, and quality.

divyasinghal@gim.ac.in

Deepti Jog is the Research Associate at Goa Institute of Management, India. She is pursuing her PhD from Goa University's Department of Management Studies. 
She has published in the field of sustainability, tourism, and the supply chain. Her recent research interests include sustainability, green consumption, the supply chain, tourism, and the textile industry.

deeptijog@gim.ac.in

To cite the article: Hinrich Voss, Matthew Davis, Mark Sumner, Louise Waite, Ilse A. Ras, Divya Singhal, and Deepti Jog (2019), 'International supply chains: compliance and engagement with the Modern Slavery Act', Journal of the British Academy, 7(s1): $61-76$.

DOI https://doi.org/10.5871/jba/007s1.061

This article is licensed under a

Creative Commons Attribution-NonCommercial-NoDerivs 4.0 Unported License.

Journal of the British Academy (ISSN 2052-7217) is published by

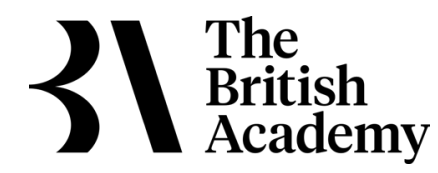

10-11 Carlton House Terrace, London, SW1Y 5AH

www.thebritishacademy.ac.uk 